LA W RENCE LIVERMORE N A TIO NAL LABORATORY

\title{
The Challenge for Arms Control Verification in the Post-New START World
}

C. R. Wuest

July 16, 2012 
This document was prepared as an account of work sponsored by an agency of the United States government. Neither the United States government nor Lawrence Livermore National Security, LLC, nor any of their employees makes any warranty, expressed or implied, or assumes any legal liability or responsibility for the accuracy, completeness, or usefulness of any information, apparatus, product, or process disclosed, or represents that its use would not infringe privately owned rights. Reference herein to any specific commercial product, process, or service by trade name, trademark, manufacturer, or otherwise does not necessarily constitute or imply its endorsement, recommendation, or favoring by the United States government or Lawrence Livermore National Security, LLC. The views and opinions of authors expressed herein do not necessarily state or reflect those of the United States government or Lawrence Livermore National Security, LLC, and shall not be used for advertising or product endorsement purposes.

This work performed under the auspices of the U.S. Department of Energy by Lawrence Livermore National Laboratory under Contract DE-AC52-07NA27344. 
The Challenge for Arms Control Verification in the Post-New START World

Craig R. Wuest

June 27, 2012 


\section{Introduction}

Nuclear weapon arms control treaty verification is a key aspect of any agreement between signatories to establish that the terms and conditions spelled out in the treaty are being met. Historically, arms control negotiations have focused more on the rules and protocols for reducing the numbers of warheads and delivery systems - sometimes resorting to complex and arcane procedures for counting forces - in an attempt to address perceived or real imbalances in a nation's strategic posture that could lead to instability.

Verification procedures are generally defined in arms control treaties and supporting documents and tend to focus on technical means and measures designed to ensure that a country is following the terms of the treaty and that it is not liable to engage in deception or outright cheating in an attempt to circumvent the spirit and the letter of the agreement.

As the Obama Administration implements the articles, terms, and conditions of the recently ratified and entered-into-force New START treaty, there are already efforts within and outside of government to move well below the specified New START levels of 1550 warheads, 700 deployed strategic delivery vehicles, and 800 deployed and nondeployed strategic launchers (Inter-Continental Ballistic Missile (ICBM) silos, Submarine-Launched Ballistic Missile (SLBM) tubes on submarines, and bombers). A number of articles and opinion pieces have appeared that advocate for significantly deeper cuts in the U.S. nuclear stockpile, with some suggesting that unilateral reductions on the part of the U.S. would help coax Russia and others to follow our lead. Papers and studies prepared for the U.S. Department of Defense and at the U.S. Air War College have also been published, suggesting that nuclear forces totaling no more than about 300 warheads would be sufficient to meet U.S. national security and deterrence needs. (Davis 2011, Schaub and Forsyth 2010) Recent articles by James M. Acton and others suggest that the prospects for maintaining U.S. security and minimizing the chances of nuclear war, while deliberately reducing stockpiles to a few hundred weapons, is possible but not without risk. $^{1}$

While the question of the appropriate level of cuts to U.S. nuclear forces is being actively debated, a key issue continues to be whether verification procedures are strong enough to ensure that both the U.S. and Russia are fulfilling their obligations under the current New Start treaty and any future arms reduction treaties. A recent opinion piece by

\footnotetext{
${ }^{1}$ James M. Acton explores a number of implications of reduced nuclear stockpiles in his article, "Low Numbers: A Practical Path to Deep Nuclear Reductions," Carnegie Endowment for International Peace, Washington, D.C 2011. For example, he suggests the U.S. should take a more comprehensive approach on arms control, "Achieving deep reductions in U.S. and Russian nuclear weapons will be difficult, for both technical and political reasons. Moreover, such reductions could create challenges to "strategic stability." As a result, U.S. arms control policy must adopt a comprehensive approach aimed at verifiably eliminating warheads (including tactical and non-deployed ones), deterring rearmament, and reducing the incentives to use nuclear weapons first in a crisis." David J. Trachtenberg argues in "U.S. Extended Deterrence: How Much Strategic Force is Too Little?" Tailored Deterrence: Influencing States and Groups of Concern, published by the USAF Counterproliferation Center, Maxwell AFB, AL, May 2011, p. 285, that the size of our stockpile directly impacts our ability to credibly assure our allies: "Nevertheless, the overall level of U.S strategic nuclear forces may convey to allies a sense of how the United States views the relevance of these forces in the contemporary security environment. Strategic force reductions, if pursued for example as part of a bilateral U.S.-Russia effort to diminish reliance on nuclear weapons for strategic deterrence purposes, may have unintended negative consequences for assurance and extended deterrence." Keith Payne is more concerned with the specifics of targeting an adversary's forces in "How Much is Enough?: A Goal-Driven Approach to Defining Key Principles," National Institute for Public Policy, 2009, p. 2, "However, there are too many uncertainties in the functioning of deterrence for confidence in claims that any particular number or types of strategic forces will deter predictably. Answering the question "how much is enough," even when done with rigor, involves speculation and a myriad of unavoidable uncertainties."
} 
Henry Kissinger and Brent Scowcroft (2012) raised a number of issues with respect to governing a policy to enhance strategic stability, including:

...in deciding on force levels and lower numbers, verification is crucial. Particularly important is a determination of what level of uncertainty threatens the calculation of stability. At present, that level is well within the capabilities of the existing verification systems. We must be certain that projected levels maintain - and when possible, reinforce - that confidence.

The strengths and weaknesses of the New START verification regime should inform and give rise to stronger regimes for future arms control agreements. These future arms control agreements will likely need to include other nuclear weapons states and so any verification regime will need to be acceptable to all parties. Currently, China is considered the most challenging party to include in any future arms control agreement and China's willingness to enter into verification regimes such as those implemented in New START may only be possible when it feels it has reached nuclear parity with the U.S. and Russia. Similarly, in keeping with its goals of reaching peer status with the U.S. and Russia, Frieman (2004) suggests that China would be more willing to accept internationally accepted and applied verification regimes rather than bilateral ones.

The current verification protocols specified in the New START treaty are considered as the baseline case and are contrasted with possible alternative verification protocols that could be effective in a post-New START era of significant reductions in U.S. and other countries' nuclear stockpiles.

Of particular concern is the possibility of deception and breakout when declared and observed numbers of weapons are below the level considered to pose an existential threat to the U.S. In a regime of very low stockpile numbers, "traditional" verification protocols as currently embodied in the New START treaty might prove less than adequate. I introduce and discuss a number of issues that need to be considered in future verification protocols, many of which do not have immediate solutions and so require further study. I also discuss alternatives and enhancements to traditional verification protocols, for example, confidence building measures such as burden sharing against the common threat of weapon of mass destruction (WMD) terrorism, joint research and development and sharing of new verification technologies, ${ }^{2}$ and even exploring exchanges of sensitive nuclear weapons data to provide the necessary level of trust enhancement to allow nations to reduce their stockpiles to very few or zero nuclear weapons in a stable manner.

\section{Verification - Past, Present, and Future}

A review of verification protocols in past nuclear weapons arms control treaties provides an interesting counterpoint to the principal arms reduction goals of each treaty. Varying levels of verification have come and gone during the nearly half century of arms reduction negotiations, in some cases reflecting the difficulties or compromises required to settle on a satisfactory agreement. In all cases, there seemed to be tacit acknowledge-

\footnotetext{
${ }^{2}$ There are many forms of technology sharing that can serve the purpose of confidence building and the U.S. is looking closely at the sharing of the development of new verification technologies. For example, the precedent has been set with the LLNL-developed Fission Meter, now patented in both the U.S. and Russia, and the T1 sensor of Sandia National Laboratories, which has undergone thorough evaluation by Russia's 12th Main Directorate (Glavnoye Upravleniye Ministerstvo Oborony) of the Ministry of Defense, more simply known as the 12th GUMO, Russia's primary military organization responsible for nuclear munitions.
} 


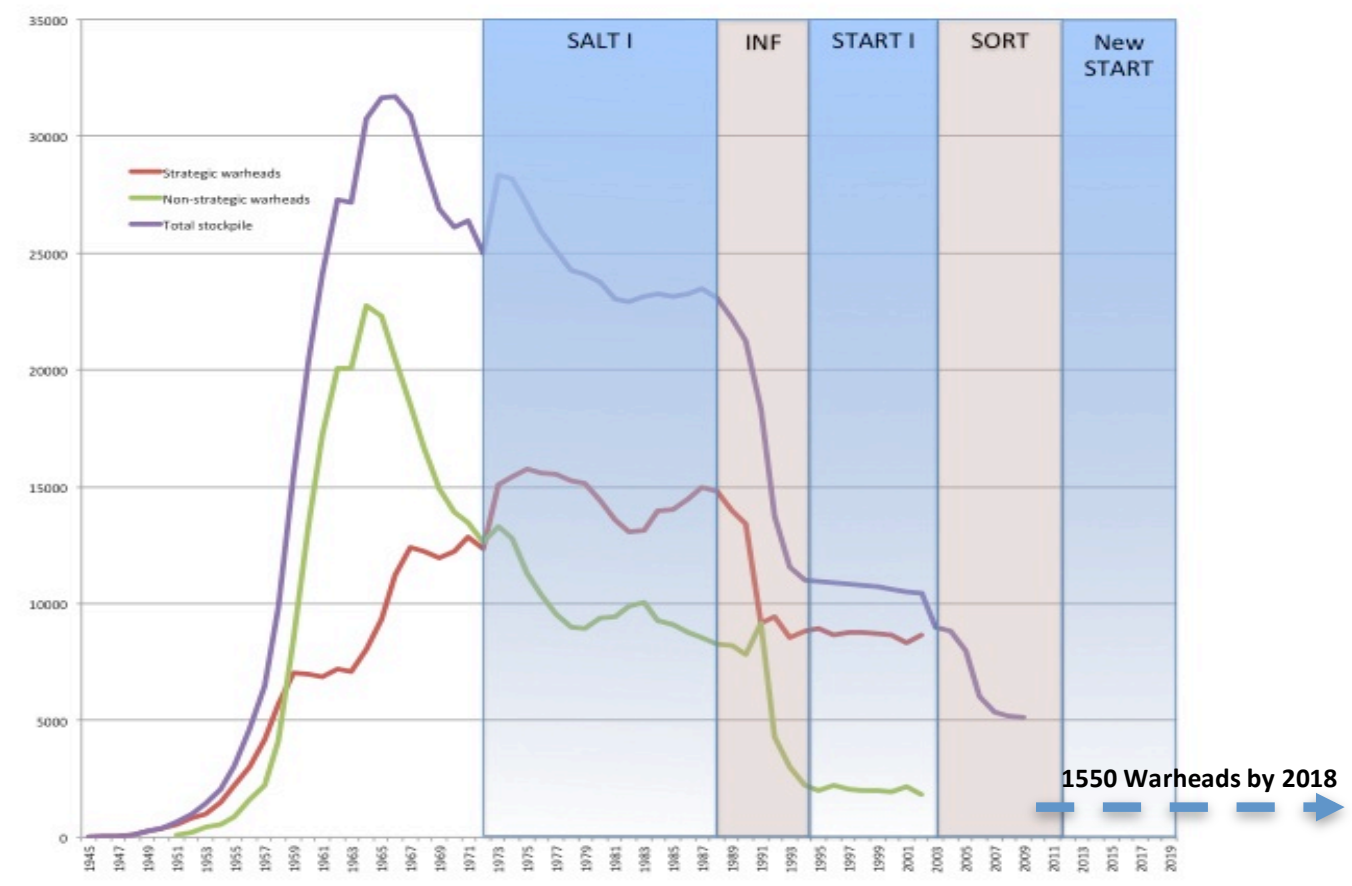

Figure 1. Estimated total U.S. nuclear weapons stockpile (active and inactive) including the most recent declaration of the total active stockpile of 5113 warheads by the U.S. Department of Energy in $2010 .^{3}$

ment that no verification regime is bulletproof to an adversary determined to deceive or cheat.

Figure 1 shows the total U.S. nuclear weapons stockpile over time overlaid on the periods of different arms control treaties. The effects these treaties have had on the total number of nuclear weapons is striking. Appendix 1 compares and contrasts all major nuclear arms control verification and compliance procedures. ${ }^{4}$ Interesting differences in verification and compliance are evident over the history of arms control, reflecting the relative confidence (or perhaps wishful thinking) of the negotiating parties, but in general, verification has relied on National Technical Means (NTM), which includes aerial and satellite reconnaissance of declared sites, radiation monitoring (for verifying declared non-nuclear objects and monitoring the movement of weapons systems from storage or production facilities), on-site inspections, and data exchanges. Compliance has utilized various bilateral commissions and conferences to allow declarations of activities, appeals, and other information exchange.

In reviewing the literature on the history of verification, there are generally two schools of thought: 1) The "trust" school, which posits that verification, while not perfect, is a valuable tool for confidence and trust building, and 2) the "cheating" school,

\footnotetext{
${ }^{3}$ Data from National Resources Defense Council (http://www.nrdc.org/nuclear/nudb/datab9.asp)

${ }^{4}$ While not explicitly included in Appendix 1, the Conventional Forces in Europe (CFE) Treaty included verification procedures that could be applicable to a future nuclear arms reduction treaty regime, particularly with regards to on-site inspections verification of force levels, see http://www.nti.org/treaties-and-regimes/treaty-conventional-armed-forceseurope-cfe/ for a detailed summary of the CFE Treaty and its verification and compliance protocols.
} 
which suggests that verification is of questionable value because cheating is always possible and the cost of enhanced verification may yield diminishing returns against an adversary determined to circumvent the verification techniques, in which case the benefits, in terms of increased confidence or security, is minimal.

Exemplifying the trust school, Greg Thielmann (May 2010) compares START I and New START verification procedures in detail and suggests that in the 15 years of START I's implementation and resolution of differences, a broader and deeper knowledge of each side's strategic systems and operating procedures has raised the level of mutual understanding and trust. Thielmann (July 2010) goes on to argue that:

New START's more streamlined and up-to-date verification system should be judged by its capabilities to provide confidence that the respective parties are complying with the specific limits of the new treaty, not the different limits of the one that has expired.

Thielmann neglects to discuss what many critics perceive as a weakening of verification procedures between START I and New START, particularly the reduced number of on-site inspections, the cap of five telemetry exchanges per year regardless of the number of test launches, and the lack of continuous portal monitoring.

Jürgen Scheffran (2010) takes the trust school of thought even further by positing a Nuclear Weapons Convention (NWC) that would be chartered to ensure verification and compliance with an outright ban on nuclear weapons. Scheffran argues that:

To eliminate their nuclear arsenals, the nuclear-weapon states must be confident that other states are in turn eliminating and not (re)building theirs. Verification measures are required to detect prohibited activities related to nuclear weapons with sufficient reliability. Adequate verification means that the residual uncertainties of noncompliance would be tolerable.

To his credit Scheffran acknowledges the fact that "as warhead numbers decline, uncertainties and risks will become more important, since just a few hidden nuclear weapons can make a significant difference." In order to be effective, the NWC would require specific mechanisms to ensure elimination of stockpiles, prevent future acquisition, and detect clandestine activities. What is not clear is how any technical means can be effective under such daunting requirements or what exactly other nations would do in response to violations. The task would be challenging under any circumstances and as Scheffran points out would require near continuous monitoring of:

a wide range of nuclear weapons objects (nuclear warheads and components, nuclear materials, equipment, facilities, delivery systems, command and control) and nuclear weapons activities (research, development, testing, production, acquisition, deployment, stockpiling, maintenance, transfer, use, threat of use, destruction, disposal and conversion).

In his assessment of START I verification protocols, Haralambos Athanasopulos (2000) cites the international legal framework of this treaty as being key:

Although verification of nuclear disarmament treaties cannot be absolute, the legal regime of verification measures established by this treaty not only ensures its effective implementation, but also, if one party covertly violates its treaty obligations on a scale and in away that could threaten the security of the other party acquiring a significant strategic advantage, the other party by virtue of the treaty's verification system could promptly discover such a violation. 
Steve Fetter (1998) argues that comprehensive disarmament is verifiable, while at the same time being less than perfect, but with acceptable risk "to reduce remaining uncertainties to a level that might be tolerable in a more transparent and trusting international environment... And although the possibility of rapid break-out will be ever present in modern industrial society, verification could provide the steady reassurance that would be necessary to dissipate residual fears of cheating."

Novel verification protocols have also been suggested over the years, including those that rely more strongly on "societal" monitoring. Joseph Rotblat (1993) writes,

The main form of societal verification is by inducing the citizens of the countries signing the treaty to report to an appropriate international authority any information about attempted violation going on in their countries. For this system of verification to be effective it is vital that all such reporting becomes the right and the civic duty of the citizen.

While Rotblat's goals seem laudable, it is unclear how citizens in countries likely to engage in deception and cheating, i.e., autocratic or totalitarian regimes, will be empowered to reveal these activities.

The cheating school includes The Heritage Foundation's New START Working Group and Paula DeSutter, former Assistant Secretary of State for Verification, Compliance, and Implementation who, while pointing out the weaker verification protocols in New START, also asserts that the Soviet Union and Russia have violated every arms control agreement the U.S. has had with them (DeSutter 2010). Consequently, she states that in order for verification to be effective one needs to take into account "the compliance history of the parties to the potential agreement; the risks associated with noncompliance; the difficulty of responding to deny violators the potential benefits of their violations; and the impact of constraints imposed on U.S. freedom of action, particularly given the risk of undetected cheating prior to a "breakout" from a regime."

John Bolton (2010) echoes DeSutter's concerns, pointing out that "at low levels, one side's noncompliance can give it a huge relative advantage that is difficult or impossible for the other to make up in the short term." Bolton also raises the specter of proliferation in the context of New START, citing the historical differences between the U.S. and Russia with regards to extending deterrence to allies. If the U.S. cannot credibly provide its nuclear umbrella "Beyond that, several friends, concerned for their security, could feel impelled to develop their own nuclear-weapons capabilities. The treaty thus increases the risk of proliferation..."

\section{New START Verification}

According to the Nuclear Threat Initiative (NTI) web site, New START provides the following verification protocols:

Verification measures for New START are based on the 1991 START I Treaty and were modified for the purposes of the new Treaty. These measures include national technical means (e.g. satellites), on-site inspections and exhibitions, data exchanges and notifications related to strategic offensive arms and facilities covered by the Treaty, and provisions to facilitate the use of national technical means for treaty monitoring. To increase transparency and confidence, the Treaty also provides for the annual exchange of telemetry data on a parity basis, for up to five ICBM and SLBM launches per year. 
The Treaty provides for 18 on-site inspections per year. These inspections are divided into two types. Type One inspections focus on sites with deployed and non-deployed strategic systems; Type Two inspections focus on sites with only non-deployed strategic systems. Each Party is allowed to conduct ten Type One inspections and eight Type Two inspections annually.

In Type One Inspections, each Party will have the right to count the number of reentry vehicles actually deployed on one ICBM or SLBM, rather than attribute a set number of warheads to each type of missile. If the inspected Party covers its reentry vehicles, each must have its own cover.

There will be no continuous perimeter and portal monitoring at missile production facilities, but Parties must provide notification within 48 hours of any treaty-limited item leaving a production facility.

Among the provisions of New START, specified in the Annex on Inspection Activities is the continued use of unique identifiers (UIDs) first implemented in START I. From the NTI web site:

Part Two [of the Annex] directs each Party to use unique identifiers (UIDs) for each existing or newly-produced ICBM, existing or newly-produced SLBM, and existing or newly- produced heavy bomber. Part One of the Protocol defines a UID as a nonrepeating alpha-numeric number that has been applied by the inspected Party to an ICBM, SLBM, or heavy bomber. This definition gives each Party the flexibility to use UIDs for its systems in a manner that is cost-effective and efficient. For certain inaccessible ICBMs, SLBMs, and heavy bombers, Part Two provides provisions for replicating UIDs and displaying them on associated equipment or locations in order for inspectors to be able to confirm during inspections the data contained in the database.

Paragraph 1 specifies the general provisions governing UIDs. Each Party must affix UIDs to each of its existing or newly-produced ICBMs, SLBMs, and heavy bombers using its own technology. The intent is to permit each Party to have the maximum flexibility in determining the mode of application and size of its UIDs. Both sides recognize that procedures that work well for one Party may not necessarily be efficient or effective for the other Party. Once a UID is applied to an item and the data from it is provided in accordance with Parts Two and Four of the Protocol, the UID for that item may not be changed.

While the use of UIDs potentially can help alleviate concerns regarding the pedigree of a particular system, access of systems in containers, tubes, and silos will force the UID to be located externally on the container, without the removal of the missile or warhead from the canister. For heavy bombers, the U.S. plans to use "tail numbers" as the UID. Thus the verification or reading of the UIDs is necessary, but not sufficient to determine the actual contents of the container and additional verification techniques will be re- 
quired, e.g., using radiation or gravimetric means to determine that the container's contents are verified.

Part Five of the Annex lists inspection equipment and procedures for making measurements, etc., including maintaining the integrity of the equipment. Section VI provides methods and procedures for use of radiation detection equipment to confirm non-nuclear objects are indeed non-nuclear. Currently, the use of radiation detection equipment to confirm that a nuclear object is indeed nuclear is not allowed. Visual inspection of covered warheads viewed on the missile or bomber is allowed. Inspectors can challenge the declaration of a non-nuclear object by requesting that it be removed to an area sufficiently far from the declared nuclear objects so that a radiation detection measurement can be made.

New START also includes an Annex on Telemetric Information, which specifies that telemetric data associated with the maximum five launches of an ICBM or SLBM shall not be denied to the other party through such means as encryption, jamming, etc.

\section{Departures from START I Verification}

Amy Woolf (2011) notes that the experience from START I has led to increased confidence and trust between the U.S. and Russia (italics added for emphasis):

... the United States and Russia have streamlined and simplified the central limits and the monitoring and verification provisions. The new treaty does not contain layers of limits and sublimits; each side can determine its own mix of land-based intercontinental ballistic missiles (ICBMs), submarine-launched ballistic missiles (SLBMs) and heavy bombers. Moreover, in the current environment, the parties were far less concerned with choking off avenues for potential evasion schemes than they were with fostering continued cooperation and openness between the two sides.

As noted earlier, critics of New START verification are very concerned with the weakening of the verification protocols when compared to START I, in particular, with the limits placed on the number of inspections, the cap on exchange of telemetric launch data and the elimination of continuous perimeter and portal monitoring of plants that produce mobile ICBMs.

Woolf (April 2011) downplays the reduction of inspections by noting that the 10 Type One and eight Type Two inspections allow previously different inspection activities to be performed during a single inspection that makes them essentially equivalent to the 28 short-notice inspections permitted under START I.

In START I the U.S. elected to continue monitoring at the Votkinsk plant, which was begun under the INF Treaty. This monitoring was discontinued in part because the U.S. felt that there was sufficient understanding of Russian ballistic missile forces based on earlier accountings from START I. Continuous monitoring has been replaced by a 48hour notification requirement for when solid-fuel ICBMs and solid-fuel SLBMs leave the production facilities. (Woolf April 2011)

The limit on telemetric exchanges was deemed sufficient, as noted by Secretary of Defense Gates who said, "the United States does not need telemetry from Russian missile flight tests to verify Russian compliance with the treaty." Woolf (December 2011) points out that this is because under New START there is no limit to missile throw weight and because the maximum number of warheads tested on a missile will not be used as the source for the number of warheads assigned to each missile. The fact that there is still a 
provision for telemetry exchange reflects both sides' willingness to increase transparency and understanding of their offensive forces.

With regards to declarations of forces, Woolf notes:

The parties will also exchange a vast amount of data about those forces, specifying not only their distinguishing characteristics, but also their precise locations and the number of warheads deployed on each deployed delivery vehicle. They will notify each other, and update the database, whenever they move forces between declared facilities. The treaty also requires the parties to display their forces, and allows each side to participate in exhibitions, to confirm information listed in the database.

During its first 11 months in force, the United States and Russia have conducted over 1,700 exchanges of notifications and several exhibitions, as mandated by the treaty. The United States has conducted 16 inspections at Russian facilities, while Russia has conducted 17 inspections at U.S. facilities. (Gottemoeller) These inspections occurred at ICBM, SLBM, and heavy bomber bases, storage facilities, conversion and elimination facilities, and test ranges. The parties have also held two sessions of the Bilateral Consultative Commission (BCC), which was established by the treaty to address implementation and compliance issues. (Woolf December 2011)

Given the disparate opinions regarding the value of verification in past and future arms control regimes, we are left to judge whether New START protocols are working in the relatively short time they have been in effect. Kingston Reif (2011) provides a positive assessment of activities undertaken to date on the occasion of the one-year anniversary of New START and writes,

[New START verification provisions] give the United States an essential window into [Russia's deployed force] composition and location -- information the United States would not otherwise have. So far, New START's implementation has proved this correct: While US satellites and other technical means provide substantial information about Russia's nuclear forces, the cooperative verification and monitoring provisions in New START afford key insights and facts on the ground that cannot be acquired by any other means.

\section{Prospects for Verification at Low Numbers}

Many of the authors referenced in this study have expressed the view that when U.S. and Soviet nuclear weapon stockpiles numbered in the tens of thousands, compliance levels approaching 100\% were not regarded as being necessary or cost effective. Under the verification procedures adopted then, it was felt that the number of weapons that could be assembled outside of treaty norms would be small in relation to the full megatonnage/throw-weight of each other's total stockpiles. Paul Nitze (1976) provides a succinct assessment in the context of SALT, stating, "I personally take the verification issue less seriously than most because the limits are so high that what could be gained by cheating against them would not appear to be strategically significant."

In the regime of low numbers, the effects of cheating can become strategically significant, which is also recognized by both schools of thought outlined above. In particular, if a country possesses the clandestine means to hold many of our cities at risk, this "countervalue" targeting can potentially pose an existential threat. If we are not able to detect cheating or breakout in time to reconstitute our deterrent posture, consisting of sufficient numbers of offensive forces (possibly including both conventional and nuclear), we 
would be in jeopardy of losing our standing as a guarantor of peace and stability at best, and of risking nuclear annihilation at worst.

Verification thus becomes supremely important in the regime of low numbers. Acton (2011) even goes so far as to resurrect strategic stability concerns, similar to those raised from the early days of the Cold War (Schelling 1966, Nitze 1976, Mearsheimer 2001) and applies it to the modern strategic landscape, which includes issues of imbalances in conventional forces, rearmament potential, survivability of nuclear forces, and missile defense.

\section{Verification Goals and Targets}

The overarching goal of verification should be to provide each country with confidence in the other's compliance with the treaty if it accomplishes three distinct objectives. (Woolf December 2011)

- First, the regime should permit the countries to detect evidence that violations might have occurred. The data collected by the monitoring systems, when combined with the restrictions in the treaty, should enable each country to identify violations that could create a significant threat to its security in a timely fashion. ${ }^{5}$

- Second, the verification regime should deter violations to the treaty. It might accomplish this objective if the country considering an activity that would violate the agreement believed that the benefits it might gain with the activity were overshadowed by the possible costs, including the financial expense and the possible consequences if the activity were detected.

- Third, the verification regime should help build confidence in the viability of the arms control treaty. Evidence that the countries are complying with limits and obligations in the treaty is a key source of confidence in the agreement.

In order to provide the highest level of assurance in future verification regimes, I recommend that the U.S. should strongly advocate for the concept of "maximum compliance." This includes full declarations of the number and locations of all deployed and non-deployed nuclear forces - both strategic and non-strategic (tactical); unlimited, intrusive inspections on short notice; exchanges of all data on production of new or refurbished nuclear weapons, unfettered access to all telemetry data, and emplacement of both active and passive systems to detect the presence and movement of nuclear warheads and their components.

Even at low numbers, it should be possible to maximize compliance based on the historical experience from past verification activities along with the current, growing body of experience in New START to quantify the risk that "militarily signification violations" would go undetected. This quantification needs to also take into account the element of time, particularly in regards to the ability to detect violations early enough to be able to respond appropriately to the threat.

In considering how to apply this concept to China, Frieman (2004) points out that China has resisted attempts to allow intrusive inspections and other mechanisms for verification. Much of this resistance stems from an unwillingness to declare the full extent of their nuclear weapons program and to allow inspection teams access to their facilities and

\footnotetext{
5 U.S. Arms Control and Disarmament Agency. Verification: The Critical Element of Arms Control. pp. 1-2. See also U.S. Arms Control and Disarmament Agency. Annual Report to Congress, 1988. Washington, 1989. p. 55.
} 
infrastructure. While some of this reluctance may be due to their discomfort with exposing potential weaknesses, more likely they are adopting a strategy that is designed to project uncertainty regarding their true strength and intentions. This strategy is incompatible with U.S. arms control verification goals and international pressure will be required to bring China into future negotiations. I make the assumption that this is achievable for the purposes of discussing future verification and compliance regimes.

In attempting to address all the aspects of a country's nuclear weapons enterprise we reiterate Scheffran's view here that what this may entail is near continuous monitoring of: a wide range of nuclear weapons objects (nuclear warheads and components, nuclear materials, equipment, facilities, delivery systems, command and control) and nuclear weapons activities (research, development, testing, production, acquisition, deployment, stockpiling, maintenance, transfer, use, threat of use, destruction, disposal and conversion).

The following list of activities should be considered as potential verification "targets. ${ }^{, 6}$ Where appropriate, I speculate on the verification measures that might be required. This list and the assessments I make is incomplete at best and would benefit from serious, detailed discussions with technology and policy experts to determine the realm of the possible, tempered by the realities of what is acceptable and achievable. In Table 1, I provide a matrix of capabilities and my assessment of their relative applicability/utility towards verification and compliance.

Table 1.

\begin{tabular}{|l|l|l|l|l|}
\hline & NTM & $\begin{array}{c}\text { On-site } \\
\text { Monitoring* }\end{array}$ & $\begin{array}{c}\text { On-site } \\
\text { Inspection }\end{array}$ & $\begin{array}{c}\text { Wide Area Aerial } \\
\text { Surveillance** }\end{array}$ \\
\hline Warhead production & & & & \\
\hline Warhead deployment & & & & \\
\hline Warhead movement & & & & \\
\hline Warhead storage & & & \\
\hline $\begin{array}{l}\text { Warhead dismantle- } \\
\text { ment/destruction }\end{array}$ & & & & \\
\hline Missile production & & & & \\
\hline Missile deployment & & & & \\
\hline Missile movement & & & & \\
\hline Missile storage & & & \\
\hline Missile dismantle- \\
ment/destruction
\end{tabular}

\begin{tabular}{|l|l|l|l} 
Little-to-no Utility & Marginal Utility & Some Utility & Good Utility
\end{tabular}

* Includes both "chain-of-custody" monitoring and persistent/continuous monitoring, e.g., embedded sensors, room, and portal monitors

** Assumed to be a combination of "traditional" Open Skies monitoring and new aerial platforms that maintain station over fixed areas for extended periods of time

6 This list is based in part on Scheffran's assessment and also on discussions between the author and LLNL Program Director Jay Zucca and Deputy Program Director Paul Rockett. 


\section{- Warhead production}

Gaining access to nuclear warhead production plants in the U.S. and Russia would provide inspectors with an unprecedented opportunity to gauge capacity, which should be distinguished from actual weapons capabilities (designs, strengths, weaknesses, vulnerabilities, etc.) Capacity, as a measure of a country's capability to produce a certain number of constituent parts making up a complete nuclear weapon, provides a means of determining what might be possible in terms of production rates, but not necessarily what actually is being produced. If a country is willing to show its capacity for warhead production, this can serve as a stabilizing move that allows parity to be maintained between parties. The best means of assessing production capabilities are through on-site inspections, which can be structured in such a way as to minimize disruption to a country's ongoing programs. The goal here is not to catch a country producing weapons outside of the norms of the treaty as much as to assess a country's investments in the capability to produce, which can also be a measure of their overall willingness to engage in a mutually-coordinated arms reduction treaty.

- Warhead deployment

Warhead deployment, includes monitoring and verifying the locations of all nuclear warheads as they are produced and distributed to different weapons systems, which requires that "chain of custody" be maintained, similar to methods used to secure, control, and track criminal evidence. Ideally, a country's warheads would be declared, tagged, and monitored continuously once they leave a production site, in a "cradle-to-grave" system. In order to effectively monitor warheads in this fashion, countries would have to agree to allow the warhead to be readily identified, either visually through the observation of a passive tag, or remotely through the detection of an emplaced active tag such as an RFID tag that can be interrogated remotely through an active RF transmitter/receiver. This identification does not require that the actual warhead be observed, just the external casing or housing, thereby ensuring that sensitive design information related to the "physics package" is protected. Challenge inspections to verify that a warhead is indeed in the casing or housing could be allowed, but this would be a significant departure from past verification practices and might be considered too intrusive. If countries were to allow direct verification of a nuclear warhead, then measurements could involve gravimetric, passive radiation detection, etc. to establish that the device is consistent with a nuclear warhead. This greatly oversimplifies the situation and doesn't take into account the possibility that a clever adversary could possibly spoof detection systems.

\section{- Warhead movement}

Monitoring warhead movement would require each country to notify the other prior to moving a warhead regardless of whether the warhead is mated to a delivery system or not. Together with warhead deployment, warhead movement is part of the chain-of-custody process. Notification would be subject to verification through random inspections to observe the warhead's tag either visually or through a remote detection of an RFID tag affixed to the warhead's container. The issue of whether any country would readily report the movement and location of its nuclear warheads, essentially, providing valuable targeting information for the adversary is problematic. Arguments can be made that if countries were serious about reducing their stockpile 
of nuclear weapons to zero, then they would be willing to adopt extreme transparency measures such as this in order to ensure stability.

\section{- Warhead storage}

Warhead storage locations would be subject to monitoring and inspection. Monitoring could involve the placement of continuous portal monitors to detect the insertion or removal of a warhead system. Another option would be to maintain nearcontinuous remote monitoring within the storage location itself. National Technical Means could also be used to monitor activities in the vicinity of storage sites. On-site inspections of storage facilities would allow verification of warheads declared to be in storage and deter removal of warheads without prior notification.

\section{- Warhead dismantlement/destruction}

Warhead dismantlement would pose a challenge in that the dismantlement of the warhead would need to be verified while not directly giving away classified design features. A procedure for warhead dismantlement would require notification and verification that a warhead previously tagged and tracked has been transported and has entered a dismantlement facility. Continuous monitoring would be required to ensure that no warheads entering a dismantlement facility leave the facility intact. Verification that a warhead has indeed been dismantled or destroyed is perhaps the most problematic part of a maximum compliance protocol. More work will be required to ensure that constituent warhead parts are not spirited away to clandestine facilities where they could easily be reassembled into operational warheads.

\section{- Missile systems monitoring}

Missile systems monitoring could use a combination of both NTM and on-site inspections for all phases - production, deployment, movement, storage, and dismantlement/destruction. Following on the successful past Intermediate-range Nuclear Forces (INF) Treaty and the current New START verification processes, missile production facilities would be required to be readily accessible and viewable, which is relatively achievable because of the scale/size of intercontinental missiles, which require large facilities and infrastructure to manufacture. Missiles that are deployed to storage or operational facilities would be tagged and tracked through on-site inspections. Operational missiles would be declared and random inspections would verify the location and status of missiles, thereby deterring parties from attempting to relocate or hide missiles.

Monitoring could involve the placement of continuous portal monitors such as seismic monitors, scales, or video systems to detect the insertion or removal of a missile system from a facility. On-site inspections of storage facilities would allow verification of missiles declared to be in storage and deter removal of missiles without prior notification. Monitoring missile movement would require each country to notify the other prior to moving a missile regardless of whether there is a warhead mated to the missile or not. This notification would be subject to verification through random inspections to observe the missile's tag either visually or through a remote detection of an RFID tag affixed to the missile. Strategic missile dismantlement can also follow established procedures developed and successfully implemented for the INF treaty that allowed inspection teams to witness the physical dismantlement/destruction of missile bodies. 


\section{- Test facilities}

Monitoring of test facilities to ensure that countries are in compliance with ongoing treaties, such as the Threshold Test Ban Treaty and the Nuclear Nonproliferation Treaty, would continue to rely on the existing wide-spread network of seismic and NTM to ensure that countries are not engaging in nuclear testing outside of the regime of the treaties. On-site inspection of test facilities, including underground test facilities and above-ground test facilities could be considered as a further means of verifying that ongoing test activities are consistent with the numbers and sophistication of nuclear weapons stockpiles for each country and do not suggest a breakout capability.

In order to promote increased transparency and confidence, researchers have proposed using each other's test facilities to conduct research and development on verification technologies that could be used in future verification regimes. This might include development of new radiation detection systems that could potential be allowed to make direct measurements of nuclear objects. The development of these types of systems would enhance verification through more direct measurements of nuclear warheads, components, and materials that are mutually acceptable to treaty parties. In addition, inclusion of other nuclear weapons states and non-nuclear weapons states in this collaborative effort could help set the stage for multi-lateral arms control and verification regimes.

\section{- Design laboratories}

Design laboratories could continue to be monitored by NTM and through cooperative engagement such as technical exchanges and leadership visits, and collaborative research and development activities similar to those suggested above for test facilities. On-site inspections, possibly under the auspices of future treaties, e.g., the Fissile Material Cutoff Treaty, if it were to be ratified and entered into force, would allow further transparency into the amounts and disposition of special nuclear materials in place at the design laboratories.

\section{- Parts monitoring}

Declaration and monitoring of parts for nuclear warheads pose many of the same challenges as monitoring of dismantled or destroyed warheads. The ability to tag and identify parts or sub-systems may only be viable through observation of the parts and determining that the parts are indeed associated with a particular warhead. This level of scrutiny would likely expose design details of the part that may be considered too intrusive unless countries were willing to share this level of detail. Maintaining control of parts locations and the movement of parts in and out of a particular facility might be more acceptable to provide a picture in the aggregate of a country's weapons activities. Requiring co-location of all parts production, storage, assembly, and dismantlement/ destruction in a single facility or site might also simplify the requirements for monitoring, verification, and assessment of a country's capacity and intentions.

\section{- Completeness of declarations}

Declaration of a country's nuclear weapons and delivery system capability is key to establishing a baseline for which all future verification activities are built on. Inaccurate or incomplete declarations at the onset of a treaty's verification and monitoring regime will leave countries doubting the veracity of the others' willingness to be a 
party to the treaty. Fortunately, START I has provided the U.S. and Russia with detailed insights into each other's weapons complexes that continues to provide confidence in the New START era. Loss of insight into Russia through reduced inspections or outright prevention of inspections would be a serious setback to any postNew START arms reduction treaty and should be prevented at all costs. Adding to the complexity in the post-New START environment is the need to include tactical nuclear weapons and their delivery systems, as well as all deployed and non-deployed strategic systems in any future declarations. The ability to verify these declarations, particularly for the large number of dispersed tactical systems in Russia will be extremely challenging.

- Aerial wide area/persistent surveillance

Advances in near-continuous aerial surveillance, such as wide-area monitoring from aircraft, balloons/airships, and satellites can help to provide added information regarding a country's nuclear activities. National Technical Means is an established capability that has proven its effectiveness as long as countries don't take measures to circumvent these systems, for example, through denial and deception practices. High altitude systems that can loiter over particular areas might provide added confidence through near-continuous monitoring of activities, possibly at a reduced cost when compared with satellite systems. Again, these systems would require countries to operate in the open and to avoid any attempts to circumvent the observations these systems would provide. Countries would also have to be willing to allow these systems over their territories and treat them as a sort of emplaced sensor or monitor not to be tampered with. The technical challenges associated with maintaining station over critical areas of a country are not to be discounted. Ultimately, the development, fielding, and maintenance of these systems could approach those of space-based systems.

\section{Risk Quantification and Minimization}

One aspect of risk quantification is the need to determine latent or potential production capabilities, i.e., the ability for a country to build missiles and warheads in quantities significant enough to constitute a break out capability. This means that future verification regimes will need to provide better insights to each others' design and production facilities.

The efforts to increase transparency into the nuclear weapons production capabilities of each country, which Acton (2011) points out would constitute a complete departure from past arms control practices, would involve inspections of both delivery platform and nuclear warhead production facilities and laboratories that have significant production capability. These inspections would not necessarily be focused on identifying missiles and warheads while they are on the production line, rather they would allow experts to ascertain the production potential associated with the infrastructure in place at these facilities in order to ensure that the upper limits on potential production is quantified to the satisfaction of the treaty parties. Production and process systems models, such as those developed at LLNL (Shang) allow detailed assessments of capabilities under a variety of assumptions regarding a nuclear weapons state's infrastructure and capabilities, and also importantly fold in the costs associated with the entire nuclear production enterprise. While current models focus on the nuclear weapons production complex, they can be 
readily applied to delivery platform production and other key elements of a country's nuclear weapons program.

Ideally, continuous monitoring of the materials and products entering and leaving these facilities would be in place, e.g., radiation portal monitors, scales, video cameras, etc. Notification of significant movements of materials, equipment, or products would need to be part of the verification protocol, along with restrictions on attempts to conceal or deceive in-place and NTM monitoring systems. Limited on-site inspections would serve to deter continuous production by interrupting activities at those sites and adding to the adversary's cost if deceptive activities were being attempted.

Taking this even further, as the U.S. consolidates its remaining nuclear stockpile around a few "common" warhead types, the need to protect secret design features, for example, by limiting the resolution of radiation detection systems, might be relaxed. In the case of the U.S. and Russia, there is likely little new to be learned from each other's specific nuclear weapons designs that could lead to a significant strategic advantage on either side (this may not be the case for China and other nuclear states). Relaxing inspection and surveillance restrictions and limitations could go a long ways towards establishing a new paradigm of trust and confidence. How this might be applied in a multi-polar arms control regime remains to be seen. However, for the P5 countries, I believe the subject of enhanced inspection techniques and methods should be raised in future treaty negotiations in an effort to ensure transparency and stability as the countries work in concert to reduce their stockpiles.

Many of the past treaties have included detailed protocols for dealing with launchers and delivery platforms as part of the overall reduction in forces. Future treaties may well elect to focus on nuclear warheads exclusively. At low numbers of warheads, delivery systems by themselves will become less a metric of destructive potential and the effort required to link and limit launchers and platforms together with nuclear warheads may not be worth the cost. In addition, strategic stability will increasingly rely on the balance of conventional forces, which are evolving to including precision intercontinental (strategic) capability along with their long-established tactical applications.

Another mechanism for building trust and cooperation would involve the banding together of key powers to fight a common enemy, in this case the threat of nuclear terrorism from Islamist state and non-state actors. James Kurth (2008) argues for a coalition of great powers, led by the U.S. to counter and respond to terrorism threats. This coalition would include Russia, India, and China, all of whom must coexist with significant Muslim elements in their societies and spheres of influence. Working together to develop a common approach and to share the burdens in dealing with problem of Islamist terrorism under a global system of law and order could help build added trust and security, leading to a greater willingness to reduce nuclear stockpiles.

Missile defense also needs to be addressed in the coming round of arms control negotiations. Already there are signs that the Russians are working to developing technical means to penetrate nascent U.S. strategic ballistic missile defenses. This includes renewed work on maneuvering reentry vehicles and non-ballistic hypersonic delivery vehicles. Future treaties should work to discourage these developments. Limiting or eliminating strategic ballistic missile defenses during the time that countries are drawing down their nuclear stockpiles would need to be considered for strategic stability purposes. This 
also relieves verification protocols from having to address new or emerging delivery systems in addition to the warheads and supporting infrastructure.

Ultimately, verification of arms reductions at low numbers will rely on the willingness and cooperation of nuclear-armed countries to work together to ensure no one country or alliance can feel it will prevail in the event of a nuclear-armed conflict during the delicate phase of nuclear disarmament that we are approaching. Countries will necessarily have to open themselves up to scrutiny in a manner never before accepted or achieved. The U.S. can lead the way in future arms control negotiations by proposing and allowing on itself novel and challenging methods for verification and compliance. In doing so, other countries will be judged based on their willingness to accept a new level of intrusiveness in order to reach the universal goal of a nuclear-free world.

\section{Acknowledgements}

I would like to express my gratitude to Professors Jasen Castillo and Joseph Cerami at the Bush School for Government and Public Service, Texas A\&M University for their instruction and guidance as I explored the issues surrounding deep reductions in U.S. nuclear weapons stockpiles during my just concluded year as a Fellow of the Scowcroft Institute of International Affairs. I would also like to thank Ambassador Ronald F. Lehman, II and Mr. T. R. Koncher for their many fascinating discussions and historical insights that helped me better appreciate how our past nearly 70 years of nuclear deterrence experience can inform our future national security posture. Finally, I am extremely grateful to Dr. Paul D. Rockett, and Dr. John J. Zucca, who have provided their support, comments, and critiques of this paper, particularly with respect to the prospects for introducing new and enhanced verification technologies in future arms control treaties. 


\section{Bibliography}

Acton, James. M. 2011. "Low Numbers: A Practical Path to Deep Nuclear Reductions." Carnegie Endowment for International Peace, Washington, D.C.

Athanasopulos, Haralambos 2000. Nuclear Disarmament in International Law, (pp. 108109) Jefferson, NC: McFarland and Company, Inc.

Bolton, John. R. 2010. "A Treaty For Utopia.” National Review Online, http://www.nationalreview.com

Davis, Paul. K. 2011. "Structuring Analysis to Support Future Decisions About Nuclear Forces and Postures." RAND Corporation Working Paper WR-878-OSD.

DeSutter, Paula A. 2010. "Verification and the New START Treaty." Heritage Lectures, The Heritage Foundation, 1160:1-6.

U.S. Department of State (DOS), Arms Control and International Security, http://www.state.gov/t/

Fetter, Steve 1998. "Verifying Nuclear Disarmament." In Nuclear Weapons: The Road to Zero, ed. Joseph Rotblat, Boulder, CO: Westview Press.

Frieman, Wendy 2004. China, Arms Control, and Nonproliferation, London: RoutledgeCurzon, p. 164.

Gottemoeller, Rose 2011. "A "New START" For Arms Control," The Hill, December

22, 2011. http://thehill.com/blogs/congress-blog/foreign-policy/200997-a-new-start-for-

arms-control.

Kissinger, Henry A. and Scowcroft, Brent. 2012. "Nuclear weapon reductions must a part of strategic analysis," The Washington Post. April 22.

Kurth, James 2008. "Boss of Bosses." In To Lead The World, eds. M. Leffler and J. Legro, New York: Oxford University Press.

Mearsheimer, John J. 2001. The Tragedy of Great Power Politics, New York: W. W. Norton and Co.

The New START Working Group. 2010. "New START: Potemkin Village Verification," Heritage Foundation Backgrounder, 2428:1-9.

The New Threat Initiative (NTI), http://www.nti.org

Nitze, Paul. H. 1976. "Assuring Strategic Stability in an Era of Détente." Foreign Affairs, 54: 207-232.

The Nuclear Threat Initiative (NTI), http://www.nti.org/treaties-and-regimes/treaties/

Reif, Kingston 2012. "New START: One Year Later.” Bulletin of the Atomic Scientists.

Rotblat, Joseph 1993. "Societal Verification”, In eds. Joseph Rotblat, Jack Steinberger and Bhalchandra Udgaonkar, A Nuclear-Weapon-Free World: Desirable? Feasible? (p. 105) Boulder, CO: Westview Press.

Schaub Jr., Gary and Forsyth Jr., James 2010. "An Arsenal We Can All Live With.” New York Times, 24 May

Scheffran, Jürgen 2010. "Verification and Security in a Nuclear-Weapon-Free World: Elements and Framework of a Nuclear Weapons Convention," United Nations Institute for Disarmament Research, Disarmament Forum: Arms control verification, 3:52-64.

Schelling, Thomas C. 1966. Arms and Influence, New Haven: Yale University Press. Shang, Clifford C. December 2005. "Modeling the Future," Science and Technology Review, Lawrence Livermore National Laboratory. 
Thielmann, Greg July 2010. "The Value of New START Verification.” The Arms Control Association, Issue Brief, 1:9:1-4.

Thielmann, Greg May 2010. "New START Verification: Up to the Challenge." The Arms Control Association, Threat Assessment Brief.

Woolf, Amy April 2011. "The New START Treaty: Central Limits and Key Provisions." Congressional Research Service.

Woolf, Amy December 2011. "Monitoring and Verification in Arms Control." Congressional Research Service 
Appendix 1: Summary of Nuclear Arms Control Treaties

\section{Adapted from Nuclear Threat Initiative Treaty Summaries (www.NTI.org)}

\begin{tabular}{|c|c|c|c|c|}
\hline Treaty & $\begin{array}{c}\text { Entered } \\
\text { Into Force }\end{array}$ & Arms Reduction Specifications & Verification/Compliance Procedures & $\begin{array}{l}\text { Additional } \\
\text { Comments }\end{array}$ \\
\hline $\begin{array}{l}\text { Strategic Arms Limita- } \\
\text { tion Treaty (SALT) I } \\
\text { Interim Agreement limit- } \\
\text { ing strategic offensive } \\
\text { arms, and the Anti- } \\
\text { Ballistic Missile Treaty }\end{array}$ & $\begin{array}{c}\text { October 3, } \\
1972\end{array}$ & $\begin{array}{l}\text { U.S. }<710 \text { launchers on } 44 \text { SSBNs } \\
\text { U.S.S.R }<950 \text { launchers on } 62 \text { subs }\end{array}$ & $\begin{array}{l}\text { The Agreement entitled the Parties to use their national tech- } \\
\text { nical means (NTM) of verification to ensure compliance } \\
\text { with the Agreement and obligated them not to interfere with } \\
\text { NTM of the other Party, nor to use deliberate concealment } \\
\text { measures that may impede verification by NTM. Compli- } \\
\text { ance: No mechanisms existed to deal with non-compliance. }\end{array}$ & \\
\hline SALT II & $\mathrm{N} / \mathrm{A}$ & $\begin{array}{l}\text { 2,400 equal aggregate limit on strate- } \\
\text { gic nuclear delivery vehicles (SNDV), } \\
\text { including ICBMs, SLBMs, and heavy } \\
\text { bombers; } 1,320 \text { equal aggregate limit } \\
\text { on MIRV systems with complex } \\
\text { throw weight rules }\end{array}$ & $\begin{array}{l}\text { Same as SALT I plus the Treaty provided for notifications } \\
\text { on a case-by-case basis of ICBM launches, except for single } \\
\text { ICBM launches from test ranges or from ICBM launcher } \\
\text { deployment areas, which were not intended to extend beyond } \\
\text { a Party's national territory. Compliance: No mechanisms } \\
\text { existed to deal with non-compliance. }\end{array}$ & $\begin{array}{l}\text { Signed } \\
\text { June } 18 \\
1979, \text { but } \\
\text { never en- } \\
\text { tered into } \\
\quad \text { force }\end{array}$ \\
\hline $\begin{array}{l}\text { Treaty between the Unit- } \\
\text { ed States of America and } \\
\text { the Union of Soviet So- } \\
\text { cialist Republics on the } \\
\text { Elimination of Their } \\
\text { Intermediate-range and } \\
\text { Shorter-range Missiles } \\
\text { (INF Treaty) }\end{array}$ & $\begin{array}{c}\text { June } 1 \\
1988\end{array}$ & $\begin{array}{l}\text { The Treaty includes the Memorandum } \\
\text { of Understanding (MOU), the Proto- } \\
\text { col on Elimination, and the Protocol } \\
\text { on Inspection. It obligates the Parties } \\
\text { to eliminate their shorter-range and } \\
\text { intermediate-range missiles and } \\
\text { launchers to such missiles, and all } \\
\text { support structures and support equip- } \\
\text { ment of the categories listed in the } \\
\text { MOU associated with such missiles } \\
\text { and launchers within three years after } \\
\text { entry into force of the Treaty. } \\
\text { The intermediate-range missile is de- } \\
\text { fined as ground-launched ballistic } \\
\text { missiles (GLBM) or ground-launched } \\
\text { cruise missiles (GLCM) having a } \\
\text { range between } 1,000 \text { km to } 5,500 \text { km. } \\
\text { The shorter-range missile is defined as } \\
\text { GLBMs or GLCMs with a range be- } \\
\text { tween } 500 \text { km and } 1,000 \text { km. } \\
\text { The Treaty bans production or flight- } \\
\text { testing of any intermediate-range or } \\
\text { shorter-range missiles or production of } \\
\text { any stages of such missiles or any } \\
\text { launchers of such missiles. }\end{array}$ & $\begin{array}{l}\text { The Treaty provides for data exchange and notifications } \\
\text { through Nuclear Risk Reduction Centers. The Parties are } \\
\text { obligated to provide notifications of the elimination of a spe- } \\
\text { cific deployment area, missile operating base, or missile } \\
\text { support facility; changes in the number or location of elimi- } \\
\text { nation facilities. The Treaty entitled the Parties to conduct } \\
\text { baseline, closeout, elimination, and quota on-site inspections, } \\
\text { both within the territory of the other Party and within the } \\
\text { territories of basing countries. } \\
\text { Continuous Portal Monitoring inspections were permitted } \\
\text { only at two facilities: Votkinsk, Russia (former SS-20 final } \\
\text { assembly facility) and Magna, Utah (former Pershing II pro- } \\
\text { duction facility.) } \\
\text { The Parties were also entitled to use national technical } \\
\text { means of verification (NTM) at their disposal in a manner } \\
\text { consistent with generally recognized principles of interna- } \\
\text { tional law. They were prohibited from interfering with NTM } \\
\text { of the other Party and using concealment measures that im- } \\
\text { peded verification of compliance with the provisions of this } \\
\text { Treaty by NTM (Article XII). } \\
\text { Compliance: The Treaty established the Special Verification } \\
\text { Commission (SVC) to resolve questions relating to compli- } \\
\text { ance with the obligations assumed; and to decide on such } \\
\text { measures as may be necessary to improve the viability and } \\
\text { effectiveness of this Treaty (Article XII). }\end{array}$ & \\
\hline
\end{tabular}




\begin{tabular}{|c|c|c|c|c|}
\hline Treaty & $\begin{array}{c}\text { Entered } \\
\text { Into Force }\end{array}$ & Arms Reduction Specifications & Verification/Compliance Procedures & $\begin{array}{l}\text { Additional } \\
\text { Comments }\end{array}$ \\
\hline $\begin{array}{l}\text { Treaty between the } \\
\text { United States of Amer- } \\
\text { ica and the Union of } \\
\text { Soviet Socialist Re- } \\
\text { publics on Strategic } \\
\text { Offensive Reductions } \\
\text { (START I) }\end{array}$ & $\begin{array}{c}\text { December 5, } \\
1994\end{array}$ & $\begin{array}{l}\text { START I established an aggregate } \\
\text { limit of } 1,600 \text { delivery vehicles and } \\
6,000 \text { warheads for each party. With- } \\
\text { in that limit, the Treaty established } \\
\text { three sub-limits: } 4,900 \text { warheads for } \\
\text { ICBMs and SLBMs, } 154 \text { heavy IC- } \\
\text { BMs (defined as having a launch } \\
\text { weight greater than } 106 \mathrm{t} \text { or a throw- } \\
\text { weight greater than } 4,350 \mathrm{~kg} \text { ), } 1,540 \\
\text { warheads for these heavy ICBMs } \\
\text { (Only the Soviet Union possessed } \\
\text { this type of missile), and } 1,100 \text { war- } \\
\text { heads for mobile ICBMs. The Treaty } \\
\text { also established a limit of } 3,600 \text { met- } \\
\text { ric tons (t) for the throw-weight of } \\
\text { ballistic missiles. }\end{array}$ & $\begin{array}{l}\text { START I verification includes: } \\
\text { 1. National Technical Means (NTMs), together with a } \\
\text { ban on actions that impair the effectiveness of } \\
\text { NTMs of the other party; } \\
\text { 2. Data exchange, including numbers and locations of } \\
\text { all deployed and non-deployed strategic delivery } \\
\text { vehicles, locations and diagrams of all facilities as- } \\
\text { sociated with strategic delivery vehicles, such as } \\
\text { bases, storage and production facilities, etc. Each } \\
\text { party is required to provide notification about any } \\
\text { change in that data shortly after it occurs. In addi- } \\
\text { tion, parties must exchange the entire set of data } \\
\text { every six months; } \\
\text { 3. On-site inspections to verify the accuracy of data. } \\
\text { Including short-notice (baseline data, data update, } \\
\text { reentry vehicle, etc.) and "planned" (verification of } \\
\text { technical data, the right to observe elimination of } \\
\text { missiles and facilities, etc.). Special verification re- } \\
\text { gime for mobile ICBMs. } \\
\text { 4. Perimeter and portal monitoring of plants that pro- } \\
\text { duce mobile ICBMs (only applied to Russia), the } \\
\text { United States continued monitoring at the Votkinsk } \\
\text { plant begun under the INF Treaty. } \\
\text { A ban on encryption of telemetry transmitted from } \\
\text { ballistic missiles during test launches and exchange } \\
\text { of all such telemetry. }\end{array}$ & \\
\hline
\end{tabular}




\begin{tabular}{|c|c|c|c|c|}
\hline Treaty & $\begin{array}{l}\text { Entered Into } \\
\text { Force }\end{array}$ & Arms Reduction Specifications & Verification/Compliance Procedures & $\begin{array}{l}\text { Additional } \\
\text { Comments }\end{array}$ \\
\hline START II & $\mathrm{N} / \mathrm{A}$ & $\begin{array}{l}\text { START II Phase I: the United States } \\
\text { and Russia were to reduce their total } \\
\text { deployed strategic nuclear warheads to } \\
\text { 3,800-4,250, including no more than } \\
\text { 2,160 warheads on SLBMs, no more } \\
\text { than } 650 \text { on heavy ICBMs, and no } \\
\text { more than } 1,700-1,750 \text { on SLBMs. } \\
\text { Phase II: each Party's total number of } \\
\text { deployed strategic nuclear warheads } \\
\text { not to exceed 3,000-3,500. Of this } \\
\text { number, no more than } 1,700-1,750 \\
\text { were to be deployed on SLBMs. Elim- } \\
\text { ination of all heavy ICBMs and all } \\
\text { ICBMs on MIRVs The MIRV ban did } \\
\text { not apply to SLBMs. }\end{array}$ & $\begin{array}{l}\text { Same as START I with observation of differences on heavy } \\
\text { bombers converted to conventional roles, and missile and } \\
\text { silo elimination or conversion. Silo conversions were also } \\
\text { subject to inspection. Additional inspections to confirm the } \\
\text { elimination of heavy ICBMs and their launch canisters, as } \\
\text { well as additional inspections to confirm the conversions of } \\
\text { heavy ICBM silo launchers. In addition, START II provided } \\
\text { for exhibitions and inspections to observe the number of } \\
\text { nuclear weapons for which heavy bombers were actually } \\
\text { equipped and their relevant observable differences. } \\
\text { Compliance: To provide a forum for discussion of imple- } \\
\text { mentation of START II, the Treaty established the Bilateral } \\
\text { Implementation Commission (BIC). Through the BIC, the } \\
\text { Parties could have resolved questions of compliance and } \\
\text { agreed upon additional measures to improve the viability and } \\
\text { effectiveness of the Treaty. }\end{array}$ & $\begin{array}{l}\text { On } 14 \text { June } \\
2002 \text {, the } \\
\text { Russian Fed- } \\
\text { eration with- } \\
\text { drew START } \\
\text { II due to US } \\
\text { refusal to } \\
\text { ratify the } \\
\text { Treaty and to } \\
\text { US with- } \\
\text { drawal from } \\
\text { the ABM } \\
\text { Treaty. The } \\
\text { Treaty is no } \\
\text { longer in ef- } \\
\text { fect. }\end{array}$ \\
\hline $\begin{array}{l}\text { Strategic Offensive } \\
\text { Reductions Treaty } \\
\text { (SORT) }\end{array}$ & June 1,2003 & $\begin{array}{l}\text { Each Party shall reduce and limit stra- } \\
\text { tegic nuclear warheads not exceed } \\
1,700-2,200 \text { for each Party with the } \\
\text { composition and structure of its stra- } \\
\text { tegic offensive arms, based on the } \\
\text { established aggregate limit for the } \\
\text { number of such warheads. } \\
\text { The Parties agree that START I re- } \\
\text { mains in force in accordance with its } \\
\text { terms. }\end{array}$ & $\begin{array}{l}\text { No specific verification or compliance provisions. For pur- } \\
\text { poses of implementing this Treaty, the parties shall hold } \\
\text { meetings at least twice a year of a Bilateral Implementation } \\
\text { Commission. START I provisions "will provide the founda- } \\
\text { tion for providing confidence, transparency, and predictabil- } \\
\text { ity in further strategic offensive reductions, along with other } \\
\text { supplementary measures, including transparency measures, } \\
\text { to be agreed." In February of } 2003 \text {, the Senate Armed Ser- } \\
\text { vices Committee, in reviewing the treaty for ratification, } \\
\text { stipulated two additional conditions. First, the creation of an } \\
\text { annual report on the status of US-Russian Cooperation } \\
\text { Threat Reduction initiatives and, second, an annual update } \\
\text { on treaty implementation, including information on strategic } \\
\text { force levels, planned reductions each calendar year, and veri- } \\
\text { fication or transparency measures. }\end{array}$ & \\
\hline
\end{tabular}




\begin{tabular}{|c|c|c|c|c|}
\hline Treaty & $\begin{array}{c}\text { Entered Into } \\
\text { Force }\end{array}$ & Arms Reduction Specifications & Verification/Compliance Procedures & $\begin{array}{l}\text { Additional } \\
\text { Comments }\end{array}$ \\
\hline New START & $\begin{array}{l}\text { February } 5, \\
2011\end{array}$ & $\begin{array}{l}\text { Limits the United States and Russia to } \\
1,550 \text { deployed strategic warheads } \\
\text { each. Warheads actually deployed on } \\
\text { ICBMs and SLBMs count toward this } \\
\text { limit while each deployed heavy bomb- } \\
\text { er equipped for nuclear armaments } \\
\text { whether with gravity bombs or ALCMs } \\
\text { counts as one warhead. The Treaty also } \\
\text { includes an aggregate limit of } 800 \text { de- } \\
\text { ployed and non-deployed ICBM } \\
\text { launchers, SLBM launchers, and heavy } \\
\text { bombers equipped for nuclear arma- } \\
\text { ments. Within that limit, the number of } \\
\text { deployed ICBMs, SLBMs, and heavy } \\
\text { bombers cannot exceed } 700 \text {. The Unit- } \\
\text { ed States and Russia must implement } \\
\text { the necessary reductions to reach these } \\
\text { limits no later than seven years after the } \\
\text { Treaty's entry into force. Within the } \\
\text { aggregate limits, each State has the } \\
\text { flexibility to determine the structure of } \\
\text { its strategic forces. }\end{array}$ & $\begin{array}{l}\text { Verification measures for New START are "modified" } \\
\text { from START I. These measures include national technical } \\
\text { means (e.g. satellites), } 18 \text { on-site inspections and exhibi- } \\
\text { tions, data exchanges and notifications related to strategic } \\
\text { offensive arms and facilities covered by the Treaty, and } \\
\text { provisions to facilitate the use of national technical means } \\
\text { for treaty monitoring. To increase transparency and confi- } \\
\text { dence, the Treaty also provides for the annual exchange of } \\
\text { telemetry data on a parity basis, for up to five ICBM and } \\
\text { SLBM launches per year. } \\
\text { Type One inspections focus on sites with deployed and } \\
\text { non-deployed strategic systems; Type Two inspections fo- } \\
\text { cus on sites with only non-deployed strategic systems. Each } \\
\text { Party is allowed to conduct ten Type One inspections and } \\
\text { eight Type Two inspections annually. } \\
\text { In Type One Inspections, each Party will have the right to } \\
\text { count the number of reentry vehicles actually deployed on } \\
\text { one ICBM or SLBM, rather than attribute a set number of } \\
\text { warheads to each type of missile. If the inspected Party co- } \\
\text { vers its reentry vehicles, each must have its own cover. } \\
\text { There will be no continuous perimeter and portal monitor- } \\
\text { ing at missile production facilities, but Parties must provide } \\
\text { notification within } 48 \text { hours of any treaty-limited item leav- } \\
\text { ing a production facility. }\end{array}$ & $\begin{array}{l}\text { Ten-part } \\
\text { Protocol to } \\
\text { the Treaty } \\
\text { and three- } \\
\text { part Tech- } \\
\text { nical An- } \\
\text { nexes to the } \\
\text { Protocol }\end{array}$ \\
\hline
\end{tabular}

